\title{
Ostry zespół aortalny pod postacią krwiaka śródściennego aorty piersiowej i brzusznej u 78-letniego pacjenta
}

\author{
Acute aortic syndrome - thoracic and abdominal aorta intramural hematoma in 78 year old male
}

\author{
Ewa Szymczyk ${ }^{1}$, Tomasz Kaszczyński ${ }^{2}$, Daniel Steter ${ }^{2}$, Karolina Kupczyńska ${ }^{1}$, Piotr Lipiec ${ }^{1}$, \\ Grzegorz Religa ${ }^{2}$, Arkadiusz Ammer ${ }^{2}$, Paulina Wejner-Mik ${ }^{1}$, Błażej Michalski ${ }^{1}$, Jarosław D. Kasprzak ${ }^{1}$ \\ ${ }^{1}$ Katedra i Klinika Kardiologii Uniwersytetu Medycznego w Łodzi \\ ${ }^{2}$ Oddział Kardiochirurgii Wojewódzkiego Szpitala Specjalistycznego im. Władysława Biegańskiego w Łodzi
}

\begin{abstract}
Pacjent w wieku 79 lat z nadciśnieniem tętniczym został przyjęty na szpitalny oddział ratunkowy z powodu nagłego, ostrego bólu w klatce piersiowej zlokalizowanego zamostkowo z uczuciem drętwienia kończyn górnych, nasilającego się przy wdechu. W elektrokardiogramie (EKG) stwierdzono miarowy rytm zatokowy o częstości 80/min oraz obniżenia odcinka ST do $1 \mathrm{~mm}$ w odprowadzeniach I, aVL i V6. Dwukrotnie oznaczone wartości markerów martwicy mięśnia sercowego nie charakteryzowały się dynamiką wzrostu typową dla ostrego zespołu wieńcowego. Uwagę zwracało podwyższone do $6200 \mathrm{ng} /$ ml. stężenie D-dimerów W badaniu echokardiograficznym (ryc. 1B) ujawniono poszerzenie aorty wstępującej do $47 \mathrm{~mm}$ (łuk $34 \mathrm{~mm}$ ) z pogrubieniem jej ścian do $12 \mathrm{~mm}$ w okolicy połączenia opuszkowo-tubularnego (czerwone strzałki), a ponadto uwidoczniono trójpłatkową zastawkę aortalną bez cech dysfunkcji oraz prawidłową funkcję skurczową lewej komory z frakcją wyrzutową (EF, ejection fraction) $60 \%$. W tomografii komputerowej (CT, computed tomography) zobrazowano asymetryczne pogrubienie do $12 \mathrm{~mm}$ ściany aorty piersiowej i początkowego odcinka aorty brzusznej (od opuszki aorty do poziomu tętnic nerkowych), bez cech odwarstwienia błony wewnętrznej aorty, co nasunęło podejrzenie krwiaka śródściennego. Pacjenta zakwalifikowano do pilnego leczenia kardiochirurgicznego. Śródoperacyjnie potwierdzono rozpoznanie wynikające z badania echokardiograficznego i CT, uwidaczniając krwiak śródścienny grubości do $20 \mathrm{~mm}$ perforujący aortę wstępującą i łuk aorty w zakresie krzywizny mniejszej. Wykonano wymianę aorty wstępującej i proksymalnej części łuku aorty, wszczepiając protezę dakronową (średnica $30 \mathrm{~mm}$ ). W pooperacyjnym badaniu echokardiograficznym uwidoczniono dobry efekt zabiegu. Hospitalizacja przebiegła bez powikłań. Pacjenta wypisano do domu w 8. dobie po operacji z zaleceniem dalszej opieki w poradniach kardiologicznej i kardiochirurgicznej oraz z zaplanowanym leczeniem na oddziale rehabilitacji kardiologicznej.
\end{abstract}

Ostry zespół aortalny (acute aortic syndrome) obejmuje grupę chorób dotyczących ściany aorty charakteryzujących się ostrym przebiegiem klinicznym, potencjalnie zagrażających życiu. Wśród nich wyróżnia się rozwarstwienie aorty (aortic dissection), krwiak śródścienny (aortic intramural hematoma) oraz wrzód drążący aorty (penetrating aortic ulcer). Krwiak śródścienny zazwyczaj powstaje bez uszkodzenia błony wewnętrznej aorty, a podstawowym patomechanizmem jest krwawienie z naczyń odżywczych aorty (vasa vasorum) do jej ściany. W porównaniu z rozwarstwieniem aorty krwiak śródścienny wiąże się z nieco lepszym rokowaniem, a w niewielkim odsetku może przebiegać bezobjawowo. W powstałej patologicznej przestrzeni w ścianie aorty dochodzi do wykrzepiania krwi i powstania krwiaka [1]. U około $10 \%$ pacjentów krwiak śródścienny może się samoistnie wchłonąc, ale w $28-47 \%$ przypadków dochodzi do progresji do typowego rozwarstwienia poprzez wtórne pojawienie się uszkodzenia błony wewnętrznej i tym samym utworzenia wrót rozwarstwienia. Ryzyko pęknięcia krwiaka śródściennego szacuje się na $20-45 \%$ [1].Podobnie jak w przypadku rozwarstwienia aorty stosuje się klasyfikację Stanford, obejmującą typ A, w którym proces patologiczny obejmuje aortę wstępująca, oraz typ $B$ bez zajęcia aorty wstępującej. Kluczowymi badaniami w diagnostyce i różnicowaniu ostrych stanów aortalnych są CT oraz echokardiografia przezprzełykowa. Istotnym elementem diagnostyki laboratoryjnej są D-dimery, których stężenie w ostrych zespołach aortalnych jest istotnie podwyższone; tym samym ujemny wynik D-dimerów z dużym prawdopodobieństwem wyklucza ostry zespół aortalny [2].

Sposób leczenia krwiaka śródściennego, podobnie jak rozwarstwienia aorty, zależy od zajęcia procesem patologicznym aorty wstępującej - $w$ typie A według klasyfikacji Stanford jest to wczesne leczenie kardiochirurgiczne. Zmiany typu B można leczyć zachowawczo, jeżeli nie ma cech niedokrwienia kończyn i narządów, cech wynaczynienia krwi poza światło aorty ani progresji dyssekcji.

\section{Piśmiennictwo}

1. Ganaha F, Miller DC, Sugimoto K, et al. Prognosis of aortic intramural hematoma with and without penetrating atherosclerotic ulcer: a clinical and radiological analysis. Circulation. 2002; 106(3): 342-348, indexed in Pubmed: 12119251.

2. Eggebrecht $\mathrm{H}$, Naber $\mathrm{CK}$, Bruch C, et al. Value of plasma fibrin D-dimers for detection of acute aortic dissection. J Am Coll Cardiol. 2004; 44(4): 804-809, doi: 10.1016/j.jacc.2004.04.053, indexed in Pubmed: 15312863.

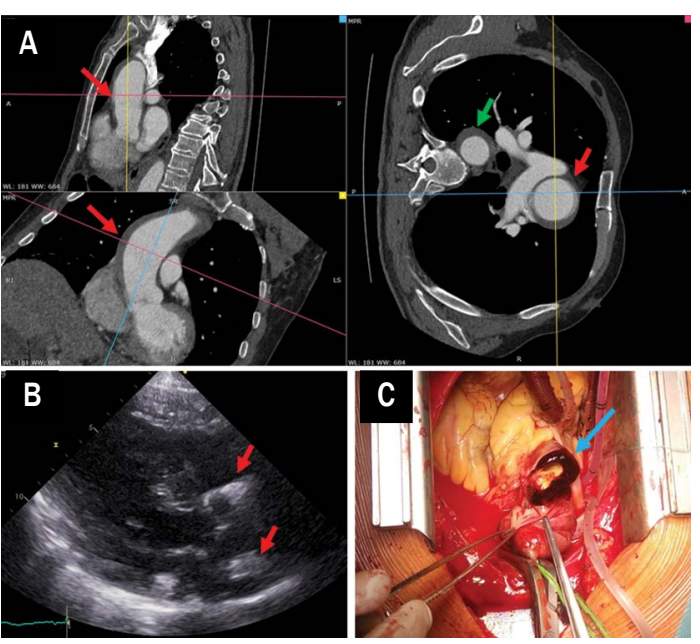

Rycina 1A. Tomografia komputerowa - uwidocznione asymetryczne pogrubienie do $12 \mathrm{~mm}$ ściany aorty piersiowej i początkowego odcinka aorty brzusznej (od opuszki aorty do poziomu tętnic nerkowych), bez cech odwarstwienia błony wewnętrznej aorty, nasuwające podejrzenie krwiaka śródściennego (czerwona strzałka - aorta wstepujaca, zielona strzałka - aorta zstępująca; B. Przezklatkowe badanie echokardiograficzne - widać poszerzenie aorty wstępującej do $47 \mathrm{~mm}$ z pogrubieniem jej ścian do $12 \mathrm{~mm}$ w okolicy połączenia opuszkowo-tubularnego (czerwone strzałki); C. Zdjęcie śródoperacyjne - niebieską strzałką wskazano asymetryczny krwiak śródścienny grubości do $20 \mathrm{~mm}$, perforujący aortę wstępującą i łuk aorty w zakresie krzywizny mniejszej.

Adres do korespondencji: dr n. med. Ewa Szymczyk, Katedra i Klinika Kardiologii, Uniwersytet Medyczny w Łodzi, Wojewódzki Szpital Specjalistyczny im. Władysława Biegańskiego, ul. Kniaziewicza 1/5, 91-347 Łódź, e-mail: eszymczyk@ptkardio.pl 